\title{
POSSIBILITY OF SAP-FEEDING BEETLE, NITIDULIDAE, AS A SPREADING AGENT FOR BLOOD DISEASE BACTERIUM ON THE BANANA PLANT
}

\author{
TJANDRA ANGGRAENI ${ }^{*}$, MASRIANY ${ }^{1,2}$, FENNY M. DWIVANY $^{1}$ and RIZKITA R. ESYANTI ${ }^{1}$ \\ ${ }^{1}$ School of Life Sciences and Technology, Institut Teknologi Bandung \\ ${ }^{2}$ Faculty of Science and Technology, UIN Alauddin Makassar \\ *E-mail: tjandra@sith.itb.ac.id
}

Accepted 25 April 2020, Published online 6 July 2020

\begin{abstract}
Banana blood disease (BBD) caused by blood disease bacterium (BDB) is one of the major diseases of Indonesian banana plants. The foraging activity of flower-visiting insects was suspected as the vectors of the disease. This study aims at analyzing the potential of the sap-feeding beetle, Nitidulidae, as a vector of BDB. Beetle collection was done by using purposive sampling method on three cultivars of banana inflorescence: Nangka, Klutuk, and Siem. The bacterium was isolated from the outside and the inside of beetle tissues and was followed with bacterial DNA extraction. Confirmation of bacterial cell culture as BDB was conducted by biochemical assay and PCR using 16S rDNA oligonucleotide. The findings revealed that the beetle population in the three cultivars of banana cultivars was Nangka (66\%), Siem (19\%) and Klutuk (16\%). According to the biochemical assay and PCR result, it has been found that the bacterial cell culture was found positive as BDB, which was putative $79 \%$ and homolog with BDB that is in accordance with the data provided by NCBI. Thereby, the discovery of BDB in sap-feeding beetle, Nitidulidae, showed that the foraging activity has the potential as an agent of spreader of BDB in banana plants.
\end{abstract}

Key words: Nitidulidae, blood disease bacterium, banana blood disease

\section{INTRODUCTION}

Banana is an important fruit plant in food and the economic sectors. However, there are major issues in banana production in Indonesia. One of which is the banana blood disease (BBD) that is caused by a blood disease bacterium (BDB). This disease affects the production of banana plants by attacking plant vascular tissue, which results in the plant death. BBD was first discovered in Selayar Island (South Sulawesi) in the early 1910. After that, the disease started to spread in Bogor and across the island of Java, Sumatra and Borneo. Currently, most of main island areas in Indonesia have been infected with this disease and since 2009 it has also spread to Malaysia. The disease has spread rapidly and caused infection in banana plants affecting all banana production centers in Indonesia.

Transmission of the disease is accelerated by the activity of flower-insect visitors that are moving from infected banana plants to the healthy banana

\footnotetext{
* To whom correspondence should be addressed.
}

plants. The blood disease is suspected to be associated with the following insects: Hymenoptera, Lepidoptera, Diptera, and Hemiptera (Mairawita et al., 2012; Leiwakabessy, 1999). According to a study in Yogyakarta, banana plantations showed that Erionota thrax Linn. was a potential vector of the BBD since it was successfully isolated from its body (Suharjo et al., 2006).

Several studies have indicated a correlation between the banana flower-visiting insects with the BDB. This research was conducted to analyze the potential of sap-feeding beetle, Nitidulidae, as a carrier of BDB from the infected banana plant to the healthy banana plant.

\section{MATERIALS AND METHODS}

\section{Insect collection}

Insect sampling was performed using a purposive sampling method on three cultivars of banana inflorescence, in which each cultivar consisted of 10 plants. The insect collection was 
made using sweeping nets (butterfly nets) with net ring diameter $30 \mathrm{~cm}$, bag length $50 \mathrm{~cm}$, and handle length $5 \mathrm{~m}$. Specifically, the insect collection was done by inserting all of the banana inflorescence into the net while slowly moving the net to the left and right to prevent damage to the banana flower. After that, the nets were pulled quickly from the inflorescences and then, the nets were dropped over the insects on the ground as it can prevent the loss of insects. In addition, the insects were sprayed with distilled water to minimize their movement It should be considered that the use of alcohol and chloroform must be avoided to prevent denaturation of the bacterial cells in the insect's body. Lastly, the insects were inserted into bottles containing distilled water using a brush and aspirator. Similar insects were stored in the same bottles. Insect identification was done using Borror et al. (1992) identification.

\section{Bacterial isolation from the beetles}

Isolation of putative BDB was conducted by repeatedly using four beetles on each cultivar of banana plant for three times. The bacterium was isolated from the external and the internal part of the beetle body with using a slightly modified Suharjo et al. (2006) method. The bacterium was then cultured in a specific medium named triphenyl tetrazolium chloride (TTC) (French et al., 1995; Kelman, 1954). The procedure of BDB isolation from the external of the beetle body is: (1) Soaking one beetle into $10 \mathrm{~mL}$ of $0.85 \% \mathrm{NaCl}$ for 10 seconds using vortex mixer by three times repetitions; (2) Diluting bacterial suspension into $10^{-1}, 10^{-2}, 10^{-3}$, $10^{-4}$, and $10^{-5}$. After that, pouring of $100 \mu \mathrm{L}$ of each serial dilution into a petri dish containing TTC medium and nystatin; and (3) Incubating the beetle in room temperature for 48-72 hours. On the other hand, the procedure of BDB isolation from the internal of beetle body is: (1) Soaking beetle tissue in a $1.5 \mathrm{ml}$ tube filled with $5 \%$ sodium hypochlorite for 5 minutes. In order to remove the residual of sodium hypochlorite, the micro tube was rinsed with sterile distilled water for about 4-5 times; (2) Crushing beetle tissue using a pestle, adding $10 \mathrm{ml}$ of $0.85 \%$ sodium chloride and stirring them to be homogenized; (3) Diluting the bacterial suspension was into $10^{-1}, 10^{-2}, 10^{-3}, 10^{-4}$, and $10^{-5}$. Then pouring of $100 \mu \mathrm{l}$ of each serial dilution into a petri dish containing TTC medium and nystatin; (4) Incubating the beetle in room temperature for 48-72 hours; and (5) Screening the bacterial cell, in which the extraction of DNA bacterial was modified Yasman's (2016) method.

\section{BDB amplification by PCR}

Polymerase chain reaction (PCR) was performed to confirm the characteristics of $\mathrm{BDB}$ genotype isolated from the beetles. This amplification of BDB DNA was performed using modified Kusumoto et al. (2004) method. The PCR profile include initiation temperature of denaturation at $95^{\circ} \mathrm{C}$ for 5 minutes, 30 cycles of denaturation at $94^{\circ} \mathrm{C}$ for 30 seconds, annealing at $62^{\circ} \mathrm{C}$ for 30 seconds and extension at $72^{\circ} \mathrm{C}$ for one minute, and the final extension at $72^{\circ} \mathrm{C}$ for 7 minutes. The PCR products were analyzed using electrophoresis (100 volts, 30 minutes) and followed by $\mathrm{EtBr}$ staining for visualization of DNA. DNA was purified from agarose gel electrophoresis using the Wizard SV Gel and PCR Clean-UP System from Promega (Catalog No. A9282). To determine the DNA sequences, the sample was sent to Macrogen Inc. for sequencing purpose. Sequencing results were analyzed by performing alignment with Bioedit v7.2.3 software, and then the sequence similarity analysis was conducted using BLAST (Claverie \& Notredame, 2003).

\section{RESULTS AND DISCUSSION}

\section{The sap-feeding beetle population, Nitidulidae, on three banana cultivars}

The population of sap-feeding beetle, Nitidulidae, on banana inflorescences, as depicted in Figure 1, showed the highest population was on the cultivar of Nangka. It reached almost 25 beetles per plant, in which the average number of beetles in this cultivar was equivalent with $67 \%$. The population of beetles on Siem and Klutuk cultivars was almost similar, which was around 6 beetles per plant that was equivalent with $16 \%$. Furthermore, the number of flower insect visitor was affected by secondary and primary metabolite released by flower scent. Typically, attractant compound is a volatile compound of secondary metabolites, while nutrients act as phagostimulant for insects. Usually, phagostimulant is the result of primary metabolites such as sugars, amino acids, and lipids (Lohaus \& Schwerdtfeger, 2014; Junker \& Blüthgen, 2010).

\section{The isolation of putative BDB from the sap- feeding beetle, Nitidulidae}

Isolation of putative BDB from the beetle tissues was performed by isolating the bacterial from the external and the internal parts of the beetle. The bacterial culture was identified morphologically through gram test, and biochemical assay. The morphological characteristics of beetle body's bacterial culture are round, reddish, with a diameter of 0.5-3 mm, non-fluidal, viscid, and forming clear zone around the colonies after 3-4 days of inoculation. The gram test showed the bacteria was gram-negative marked with sticky reaction when a bacterial culture was applied to a solution of $3 \%$ $\mathrm{KOH}$. These bacterial test results (Table 1) are similar 


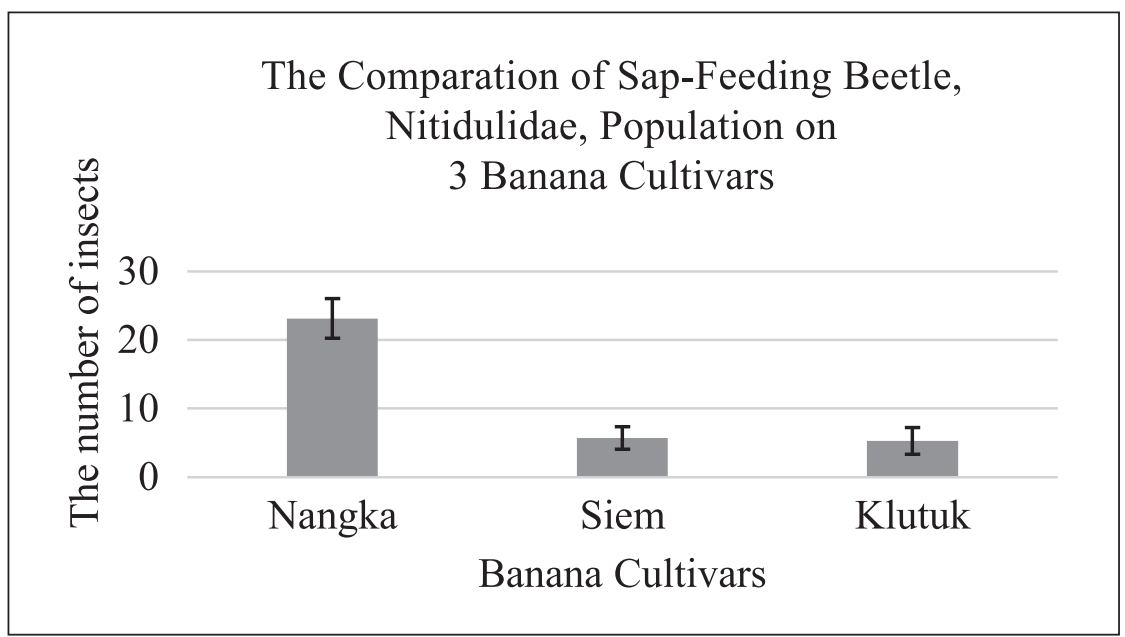

Fig. 1. The number of sap-feeding beetle, Nitidulidae, on three banana cultivars: 25 beetles on Nangka cultivar, 6 beetles on both Siem and Klutuk cultivars.

Table 1. Result of Biochemical assay of Bacterial culture from sap-feeding beetle, Nitidulidae

\begin{tabular}{clc}
\hline No & Biochemical assay & Result \\
\hline 1 & Urease & - \\
2 & Gelatin & - \\
3 & Hydrolysis of starch & - \\
4 & TSA & + \\
5 & Indol & - \\
6 & Motility & + \\
7 & $\mathrm{H}_{2} \mathrm{~S}$ & - \\
8 & Methyl Red & + \\
9 & Casein hydrolysisis & - \\
10 & TSI & + \\
11 & Simon sitrat & + \\
12 & Carbohidrat fermentation & + \\
13 & Voges & - \\
\hline
\end{tabular}

Table 2. The number of putative BDB isolated from internal and external body parts of sap-feeding beetle, Nitidulidae, taken from three cultivars. The beetles with highest putative BDB were found on Nangka cultivar

\begin{tabular}{lcc}
\hline \multirow{2}{*}{ Banana cultivar } & \multicolumn{2}{c}{ Part of Beetle Isolation } \\
\cline { 2 - 3 } & Internal & External \\
\hline Nangka & $3,66 \pm 0,57$ & $4,0 \pm 0$ \\
Siem & $1,66 \pm 0,57$ & $2,336 \pm 0,57$ \\
Klutuk & $0 \pm 0$ & $1,33 \pm 0,57$ \\
\hline
\end{tabular}

to the characteristics of BDB tested by Supriadi (2003; 2005), Baharuddin et al. (1994), and Rustam (2007).

The beetles on three banana cultivars showed that the beetles with highest putative BDB were found on Nangka both in the external and the internal body parts of beetle (Table 2). The isolation of putative BDB on Klutuk cultivar showed that there was no BDB cell from internal body part of beetle, in contrary, the external body parts of the beetle contains bacterial cell. This may be due to the absence of the BDB in the inflorescence of the Klutuk cultivar, or the beetle might not conduct foraging activities, hence, the possibility to carry the bacterial cells from the inflorescence became very small.

\section{Putative BDB amplification by PCR}

The electrophoresis result showed that there was one band of DNA of about 1,500 base pairs (Figure 2 ). The blast of sequencing results had $79 \%$ similarity with DNA sequences BDB A2 HR-MARDI (Figure 3). According to Claverie \& Notredame (2003), this confirms that bacterium isolated from the body of the banana flower-visiting insects is BDB.

The sap-feeding beetle, Nitidulidae, is the banana flower visitor that is potent as a spreading agent of blood disease bacterium (BDB) on banana plant. The foraging activity of sap-feeding beetle,

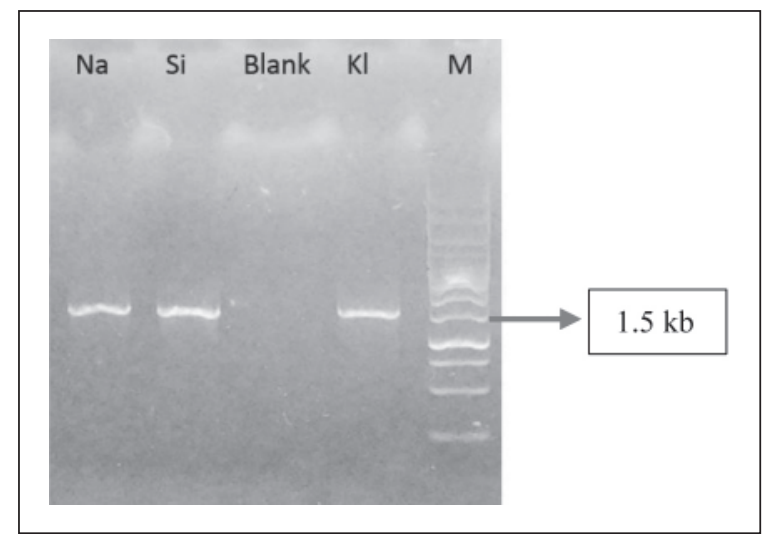

Fig. 2. Electrophoreris result showing one band of DNA consisting 1,500 base pairs. 


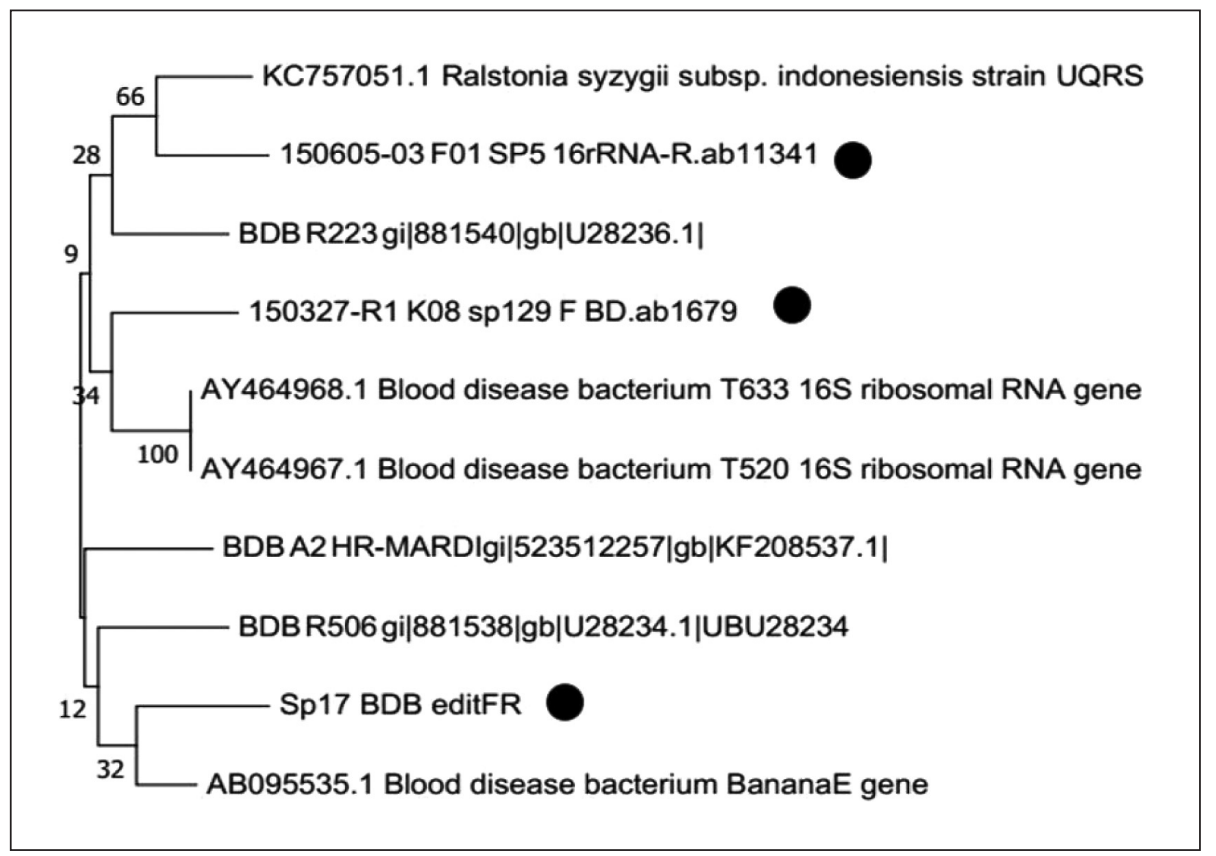

Fig. 3. Phylogenetic tree of putative BDB isolated from sap-feeding beetle, Nitidulidae, after constructed with Neighbor Joining according to 16SrDNA.

Nitidulidae, on banana inflorescence from infected banana plant to the healthy banana plant is possible, transmitting the bacterial cells. It has been confirmed that the sap-feeding beetle, Nitidulidae, contains the putative BDB.

\section{ACKNOWLEDGEMENTS}

Authors extend their gratitude to the Indonesian Ministry of Research and Higher Education for the financial grants (KLN, grant no: 1139/I1.C02.2/PL/ 2016) and the School of Life Sciences and Technology of Institut Teknologi Bandung for allowing the use of laboratory facilities of this research.

\section{REFERENCES}

Baharuddin, K., Rudolph. \& Niefold, F. 1994. Production of monospesific antiserum against the blood disease bacterium affecting banana and plantain. Phytopathology, 84: 570-575.

Borror, D.J., Triphlehorn, C.A. \& Johson, F.N. 1992. Pengenalan pelajaran serangga. Yogyakarta: Gadjah Mada University Press.

Claverie, J.M. \& Noterdame, C. 2003. Bioinformatic for Dummies. Indianapolis (US): Wiley Publishing.
French, E.B., Alley, G.P. \& Elphinstone, J. 1995. Culture media for Ralstonia solanacearum isolation, identification, and maintenance. Fitopatologia, 30(3): 126-130.

Junker, R.R. \& Blüthgen, N. 2010. Floral scents repel facultative flower visitors, but attract obligate ones. Annals of Botany, 105(5): 777-782.

Kelman, A. 1954. The relationship of pathogenicity in Pseudomonas solanacearum to colony appearance on a tetrazolium medium. Phytopathology, 44: 693-695.

Kusumoto, S., Aeny, T.N., Mujimu, S., Ginting, C., Tsuge, T. \& Tsuyumu, S. 2004. Occurrence of blood disease of banana in Sumatra, Indonesia. Journal of General Plant Pathology, 70(1): 4549.

Leiwakabessy, C. 1999. Potensi beberapa jenis serangga dalam penyebaran penyakit layu bakteri Ralstonia (Pseudomonas) solanacearum Yabuuchi et al. pada pisang di Lampung. Tesis. Bogor: Program Pascasarjana Institut Pertanian Bogor.

Lohaus, G. \& Schwerdtfeger, M. 2014. Comparison of Sugars, Iridoid Glycosides and Amino Acids in Nectar and Phloem Sap of Maurandya barclayana, Lophospermum erubescens, and Brassica napus. PLoS One 9(1): 1-8.

Mairawita, Trimurti, H., Nasril, N. \& Suswati. 2012. Potensi serangga pengunjung bunga sebagai vektor BDB bakteri (Ralstonia solanacearum Phylotipe IV) pada pisang di Sumatera Barat. Jurnal Entomologi Indonesia, 9(1): 38-47. 
Rustam. 2007. Uji Metode Inokulasi dan Kerapatan Populasi Blood Disease Bacterium pada Tanaman Pisang. J. Hort, 17(4): 387-392.

Suharjo, R., Martono, E. \& Subandiyah, S. 2006. Potensi Erionota thrax sebagai agen penyebar patogen penyebab penyakit layu bakteri pada tanaman pisang (Blood disease bacterium). J.HPT Trop., 6(2): 100-106.

Supriadi. 2003. A simple method for distinguishing isolates of blood disease bacterium (BDB) from Ralstonia solanacearum through detection of bacteriophage production. Australasian Plant Pathology, 32: 429-431.
Supriadi. 2005. Present Status of Blood Disease in Indonesia. In C. Allen. P. Prior. A.C. Hayward. Eds. Bacterial Wilt Disease and The Ralstonia solanacearum Species Complex: ST. Paul. APS Press, Minnesota: 395-404.

Yasman, A. 2016. Identifikasi morfologi dan molekular menggunakan penanda DNA mtCOI (Mitochondrial Cytochrome Oxidase I) pada serangga diptera tanaman pisang (Musa paradisiaca) terjangkit Blood Disease. Skripsi. Institut Teknologi Bandung. Bandung. 
